\title{
Incidence of Congenital Pyloric Stenosis in Malta
}

\author{
E. A. CACHIA and F. F. FENECH
}

From St Luke's Hospital, Malta

The first operation for congenital pyloric stenosis in Malta was carried out in I949. Up to that time it was thought that this disease did not exist locally. However, an increasing number of cases have been diagnosed since then: presumably this is due to more accurate diagnosis and to the fact that doctors have become more aware of its existence. The purpose of this paper is to review the incidence of congenital pyloric stenosis in Malta as well as to compare this incidence to that of other countries.

\section{TABLE I}

INCIDENCE OF CONGENITAL PYLORIC STENOSIS BETWEEN 1952-1964

\begin{tabular}{c|c|c|c}
\hline Year & No. of Live Births & No. of Cases & \% Annual Incidence \\
\hline 1952 & 8,501 & 8 & 0.049 \\
1953 & 8,302 & 4 & 0.048 \\
1954 & 8,287 & 6 & 0.072 \\
1955 & 7,899 & 3 & 0.038 \\
1956 & 7,794 & 5 & 0.064 \\
1957 & 8,117 & 11 & 0.135 \\
1958 & 7,872 & 5 & 0.063 \\
1959 & 7,825 & 6 & 0.076 \\
1960 & 7,847 & 7 & 0.089 \\
1961 & 7,674 & 3 & 0.039 \\
1962 & 7,506 & 8 & 0.106 \\
1963 & 6,672 & 11 & 0.164 \\
1964 & 6,359 & 12 & 0.188 \\
\hline Totals & 100,655 & 89 & \\
\hline
\end{tabular}

\section{Clinical Material}

Between 1952 and 1964, 89 cases of congenital pyloric stenosis were seen at St Luke's Hospital. Ramstedt's operation was carried out on all the cases. Table I shows the number of cases per year in relation to the number of live births. Of these patients, 50 were under the care of one of us (E.A.C.), and Table II shows the birth order of these 50 patients. The incidence in the first-born and second-born child was practically equal, both groups making up $64 \%$ of the series. Cases in later-born children did occur and one of the children affected was the twelfth child. Of the 89 patients, 65 were male and 24 were female. There were 2 cases in a family with 3 children, the first two

Received May 17, 1965. born were affected and both patients were male. The youngest child operated on was Io days old and the oldest was 4 months.

TABLE II

BIRTH ORDER OF SO PATIENTS

\begin{tabular}{|c|c|}
\hline Birth Order & No. of Patients \\
\hline $\begin{array}{c}\text { Ist } \\
\text { 2nd } \\
\text { 3rd } \\
\text { 4th } \\
\text { 5th } \\
\text { 6th } \\
\text { 7th } \\
\text { 8th } \\
\text { 9th } \\
\text { 1oth } \\
\text { 1 rth } \\
\text { 12th }\end{array}$ & $\begin{array}{r}17 \\
15 \\
7 \\
2 \\
1 \\
1 \\
1 \\
2 \\
1 \\
12 \\
1\end{array}$ \\
\hline
\end{tabular}

In Malta, there are no records of the proportion of first-born in the country as a whole, so the births that took place between 1960 and 1964 in the maternity unit of this hospital were accordingly analysed. We believe that this is fairly representative of the whole island as the admissions to our hospital are unselected. Stillbirths were excluded. Table III shows the number of first-born and later-born occurring in the last five years of the period under review. The percentage of first-born is $25.55 \%$.

TABLE III

ADMISSIONS TO THE MATERNITY SECTION OF FIRSTAND LATER-BORN

\begin{tabular}{c|c|c|c}
\hline Year & No. of Live Births & First-born & Later-born \\
\hline 1960 & 2,214 & 589 & 1,625 \\
1961 & 2,242 & 446 & 1,796 \\
1962 & 2,112 & 508 & 1,604 \\
1963 & 2,043 & 506 & 1,537 \\
1964 & 1,988 & 660 & 1,328 \\
\hline
\end{tabular}

\section{Discussion}

The incidence of pyloric stenosis is affected by such factors as sex, birth order, heredity, and race. The increasing tendency for the disease to affect 
the first-born children and males has been amply confirmed by this study. McKeown and MacMahon (1955) found that the offspring of parents, one of whom had recovered from pyloric stenosis, were more liable to develop pyloric stenosis when the mother was the affected parent. This has further been confirmed by Carter (I96I).

Carter and Savage (I95I) in their study on 4 first-cousin twins found that identical twins seemed to be more affected than fraternal twins of like sex, and that the incidence was higher than in the general population. Moreover, children of men and women who recovered from pyloric stenosis had an increased liability of developing the disease (Carter and Powell, 1954; McKeown and MacMahon, 1955). Carter (196r) states, 'relatives of female index patients have considerably higher risk of being affected. For any index patient the risk of being affected is rather higher in female than in male relatives'. As more survivors of infantile pyloric stenosis begin to have their own families, the number of particularly susceptible newborn seems likely to increase (Lancet, 1956), though Wallgren (I960) has reported that the incidence in Gothenburg has actually gone down from 0.4 to $0.199 \%$.

Racial factors also play an important role. In the United States, the incidence in the Negro is significantly lower than in the white population (Laron and Horne, 1957). In Europe most of the evidence suggests that the disease is more common in the Northern European countries such as Sweden and the United Kingdom. In Italy, it is reported to be rare (Cocchi, 1950). Wallgren (194I) quoted Eckhaus from Turkey who demonstrated the rarity of pyloric stenosis in that country. Laron (1955) reported the lower incidence in Israel as compared to that in Sweden. Infantile pyloric stenosis is unknown in Malaya (Field, I95I) and it has not been reported in the Australian Aborigine (Watson, 1956). In Malta, the incidence over a 13-year period is $0.088 \% \pm 0.114$. This incidence is higher than that of Israel and presumably higher than that of Italy and Turkey. Of the 89 patients, 7 had typical English surnames. At the start of its association with Britain in 1800, Malta's population was 90,000 ; it has now increased to just over 300,000 . In these 160 years, marriages between the Maltese and British servicemen were not infrequent. We believe that this genetic mix-up of the Maltese population could well account fơ the higher incidence of congenital pyloric stenosis in Malta as compared to that of neighbourin Mediterranean countries.

TABLE IV

INCIDENCE OF PYLORIC STENOSIS IN DIFFERENI COUNTRIES

\begin{tabular}{|c|c|c|c|}
\hline Country & Year & Author & $\%$ Incidence $\overrightarrow{0}$ \\
\hline $\begin{array}{l}\text { England } \\
\text { Israel } \\
\text { Italy } \\
\text { Malaya } \\
\text { Malta } \\
\text { Scotland } \\
\text { Sweden } \\
\text { Sweden } \\
\text { Turkey }\end{array}$ & $\begin{array}{l}1946 \\
1955 \\
1950 \\
1951 \\
1965 \\
1956 \\
1941 \\
1960 \\
1941\end{array}$ & $\begin{array}{l}\text { Davison } \\
\text { Laron } \\
\text { Cocchi } \\
\text { Field } \\
\text { Present study } \\
\text { McLean } \\
\text { Wallgren } \\
\text { Wallgren } \\
\text { Eckhaus }\end{array}$ & 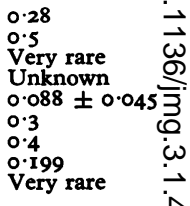 \\
\hline $\begin{array}{l}\text { White } \\
\text { Negro }\end{array}$ & $\begin{array}{l}1957 \\
1957\end{array}$ & $\begin{array}{l}\text { Laron and Horne } \\
\text { Laron and Horne }\end{array}$ & $\begin{array}{l}0.12 \pm 0.04 \text { व } \\
0.046 \pm 0.0440\end{array}$ \\
\hline
\end{tabular}

This paper reviews the incidence of congeniti pyloric stenosis in Malta. There were 89 patien who presented during the 13-year period, giviog an annual incidence of $0.088 \%$. This is below that found in the United Kingdom and Sweden and higher than that of some Mediterraneam countries.

\section{REFERENCES}

Carter, C. O. (I96I). The inheritance of congenital pyloric stenosis. Brit. med. Bull., 17, 251 .

, and Powell, B. W. (1954). Two-generation pyloric stenosis. Lancet, $\mathrm{I}, 746$.

, and Savage, T. R. (I95I). Pyloric stenosis in four first cousing

Arch. Dis. Childh., 26, 50.
Cocchi, C. (1950). Manuale di Pediatria, and ed., ed. G. Frontâ. p. 951. Minerva Medica, Torino.

Davison, G. (1946). The incidence of congenital pyloric stenosis. Arch. Dis. Childh., 21, 113.

Eckhaus, cited by Wallgren (r94I).

Field, C. E. (I95I). Congenital hypertrophic pyloric steno@s. Lancet, 2, 452 .

Lancet (1956). Infantile pyloric stenosis. I, 732.

Laron, Z. (1955). Incidence of hypertrophic pyloric stenosis in various Jewish communities in Israel. Acta paediat. (Uppsalg), 44, 40 .

44, and Horne, L. M. (1957). The incidence of infantile pyloxic stenosis. Amer. F. Dis. Child., 94, 15 r.

McKeown, T., and MacMahon, B. (I955). Infantile hypertroptinc pyloric stenosis in parent and child. Arch. Dis. Child., 30, 4970

McLean, M. M. (1956). The incidence of infantile pyloric sten@s in the north-east of Scotland. ibid., 3I, 481 .

Wallgren, A. (I94I). Incidence of hypertrophic pyloric stenosis.

Amer. F. Dis. Child., 62, 751 .
(1960) Is the rate of hypertrophic pyloric stenosis declining Acta paediat. (Uppsala), 49, 530.

Watson, J. (1956). Infantile pyloric stenosis. Lancet, 2, 517. 